\title{
Occupational risk management of equipment intended for charging electric vehicles
}

\author{
Georgeta Buica ${ }^{1 *}$,Anca Elena Antonov ${ }^{1}$, Constantin Beiu $^{1}$, Dragoș Pasculescu ${ }^{2}$, and \\ Remus Dobra ${ }^{3}$ \\ ${ }^{1}$ INCDPM “Alexandru Darabont”, 35A Blvd Ghencea, 6th county, Bucharest 062692, Romania, \\ ${ }^{2}$ University of Petrosani, 20 Universitătii st., Petrosani 332006, Hunedoara, Romania \\ ${ }^{3}$ University "1 Decembrie 1918" Alba-Iulia, Romania
}

\begin{abstract}
Implementing the objectives set at the European and national level to minimize dependence on fossil fuels and mitigate the impact of transport on the environment by introducing fiscal facilities has led to an increase in the market for electric vehicles. This increase requires the development and expansion of charging infrastructure for electric vehicles. The transition from the supply of classic fuel vehicles to the electric ones led to the elimination of some risks and the appearance of new risks for the charging stations' maintenance staff and the users. The study presents research on the identification of technical and safety requirements specific to a category of work equipment used to charge electric vehicles - charging stations. The technical and safety requirements applicable to electric vehicle charging stations have the role of providing the criteria underlying the management of the necessary risk management of both manufacturers and users and entities that ensure the maintenance of this equipment to adopt highly technical solutions.
\end{abstract}

\section{Introduction}

Implementing the objectives set at the European and national level to minimize dependence on fossil fuels and mitigate the impact of transport on the environment by introducing fiscal facilities has led to an increase in the electric vehicles (EV) market. This increase also requires the development and expansion of charging infrastructure for $\mathrm{EV}$.

Statistical data on the share of EV in the total fleet of vehicles, at the national level, processed in research studies, indicate that there is a significant increase in recent years, according to the INS record in section G. Sustainable development - 2020 Horizon Renewable energy sources - The share of electric vehicles in the total fleet of vehicles presented in Fig. 1 [1].

\footnotetext{
*Corresponding author: gbuica@protectiamuncii.ro
} 


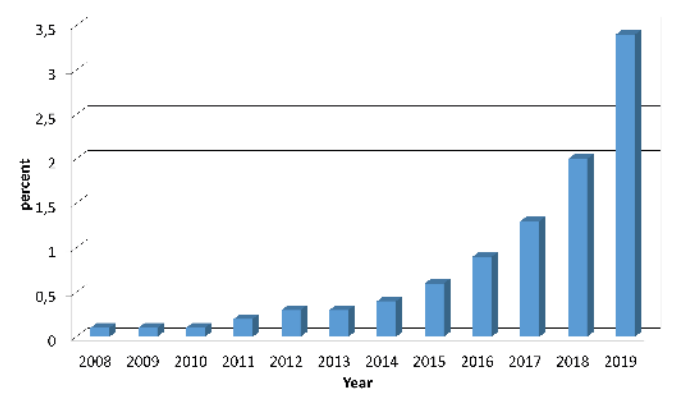

Fig. 1. The share of electric vehicles fleet in Romania,2008-2019

At the national level, policies have been established to develop the alternative fuels market following existing EU environmental and climate protection legislation. The national targets and objectives necessary for installing the infrastructure for alternative fuels, respectively electricity, were established in compliance with art. 7 (1) $\div$ (3) of Law no. 34/2017 on installing infrastructure for alternative fuels. The law sets out minimum requirements for creating alternative fuel infrastructure, including recharging points for electric vehicles to be implemented through national policy frameworks and standard technical specifications for recharging points and user information requirements [2, 4].

The law does not establish the technical and safety requirements specific to these categories of equipment used to charge electric vehicles.

The most commonly used solution for recharging an electric vehicle is cable charging in alternating current (AC) or direct current (DC). AC charging is used for conventional / semifast charging at homes and offices and in most public recharging stations. Direct current (DC) is used for fast charging.

According to the Plugshare portal, in Romania, in June 2021, the number of charging stations reached 821 . EV and charging infrastructure has 1513 charging stations/chargers, of which 1257 are charging stations with Type 2 charging Coupler, and 268 are CHAdeMO type and CCS / SAE. The same portal registered in June 2021, $7120 \mathrm{EV}$ that used these charging stations [3. 16]

High complex systems of electric vehicles required security protocols to be developed in accordance with the available advance technology and special technical equipment. System of EV supply, control systems and drive system of EVs are based on power electronics units that run at very high frequencies. Also, present in EVs are: high voltages, high currents and specific problems of DC circuits. This shows that extreme rapid evolving process of standardization is present in this industry [5].

DC charging stations are used to charge electric vehicles (EV) in direct current, providing all the necessary functions for converting the voltage and/or electric current provided by the electricity network. The charging method is 4-way, which provides advanced control overcharging through communication between the station and the vehicle.

DC charging stations can be used outdoors or indoors, depending on the technical characteristics declared by the manufacturer. From an electrical point of view, they can be classified according to the received power, the transformation ratio, the output voltage (up to $60 \mathrm{~V}$ and over $60 \mathrm{~V}$ up to $1500 \mathrm{~V}$ ), the control mode (adjustable or non-adjustable) and the degree of protection provided against electric shocks, respectively the type of electrical separation of the DC output circuit from the AC circuit of the power supply system (essential insulation, reinforced insulation and double insulation) $[7,8]$. 
Considering the fact that these products fall under the provisions of the European legislation regarding the free movement of products within the European Union, following the need to ensure compliance with the essential safety and health requirements, set out in the European legislation (Directive 2016/35 / EU, Directive 2009/127/EC, Directive $2009 / 104$ / EC), the research study focuses mainly on the analysis performed to identify the measures needed to be adopted to increase the compliance rate in the use of work equipment (WE) and new technologies for loading direct current (DC) cable of the charging stations of these categories of equipment. The methods used are:

- identification of professional risks applicable to charging stations for charging electric vehicles, which fall into the category of electrical equipment intended for use within certain voltage limits, and which is the subject of analysis in the project;

- establishing the essential safety and health requirements applicable to charging stations for charging electric vehicles, according to the legal provisions specified in Annex no. 1 of GD no. 409/2016, which adopts the LVD Directive 2016/35 / EU (directive for the design of electrical equipment intended use within certain voltage limits);

- establishing the safety and health requirements applicable to charging stations for charging electric vehicles, according to the legal provisions set in Annex no. 1 of GD no. 1166/2006, which adopts Directive 2009/104 / EC (directive on the use of work equipment);

\section{Safety requirements for work equipment intended for charging electric vehicles in direct current}

The case study analysed in this project focused on analysing charging stations in DC to establish the methodology for assessing the conformity of charging stations for charging electric vehicles, which must ensure the safety objectives set by LVD Directive 2016/35 / EU.

The expression of the safety objectives of the electrical equipment intended for use within certain voltage limits generates the need to establish the relevant safety and health requirements for ensuring the presumption of conformity.

In order to facilitate the assessment of compliance with those objectives, it is necessary to provide for the assessment of the extent to which the presumption of conformity is guaranteed for electrical equipment which complies with the harmonized standards adopted following Regulation (EU) No 182/2011. 1025/2012 on European standardization in order to express the detailed technical specifications of the respective objectives.

For this purpose, the research study established the occupational safety and health requirements specific to electric vehicle charging systems, identifying the relevant safety objectives based on the provisions of European and national legislation in occupational safety and health, standards and the regulations applicable to these categories of WE.

Equipment intended for EV charging must meet the requirements provided by GD no. $409 / 2016$ on establishing the conditions for making available on the market low voltage electrical equipment, GD no. 1146/2006 on the minimum safety and health requirements for the use at work by workers of work equipment, applicable European and national standards, respectively Law no. 34/2017 on the installation of infrastructure for alternative fuels [4].

From the analysis of the regulations in force applicable to the equipment/stations / charging systems of electric vehicles, regardless of the charging mode, eight general requirements are imposed regarding the users' health and safety and of the assembly and maintenance operators. These are related to construction, functionality (including load control), electrical safety, mechanical, thermal and chemical safety, environment and electromagnetic compatibility.

Load control/communication, starting / stopping the loading process are essential elements. For charging control, the pilot control circuit is the main control means to ensure 
correct and safe operation when connecting an electric vehicle to an equipment/charging station. [6]

The DC charging equipment must be constructed in such a way that an EV can be connected to the power supply equipment, under normal conditions of use, the transfer of energy through the conduit must be carried out safely, and its performance must be reliable and minimize the risk of danger to the user or the environment $[7,8]$

Starting from these general requirements, depending on the charging stations' type and characteristics, the specific safety and health requirements were established, summarized in Table $1[2,4,7,8,12-15]$.

Table 1. An exhaustive list of identified risks for EV charging stations in DC, respectively of the minimum safety requirements and checks established to demonstrate the presumption of conformity

\begin{tabular}{|c|c|c|c|c|c|}
\hline \multirow[b]{2}{*}{$\mathrm{S} / \mathrm{N}$} & \multirow[b]{2}{*}{$\begin{array}{l}\text { Technical and safety } \\
\text { requirements on }\end{array}$} & \multicolumn{3}{|c|}{ Safety requirements } & \multirow[b]{2}{*}{$\begin{array}{c}\text { Technical } \\
\text { condition } \\
\text { IEC } 61851- \\
23\end{array}$} \\
\hline & & $\begin{array}{l}\text { Objectives } \\
\text { GD no. } \\
409 / 2016\end{array}$ & $\begin{array}{c}\text { Legal } \\
\text { provision } \\
\text { Law no. } \\
34 / 2017\end{array}$ & $\begin{array}{c}\text { Legal } \\
\text { provision } \\
\text { GD no. } \\
1146 / 2006\end{array}$ & \\
\hline 1. & $\begin{array}{l}\text { Non-conformity of } \\
\text { materials and component } \\
\text { (e.g. Low dielectric } \\
\text { strength, breakable, UV } \\
\text { resistant, etc.) }\end{array}$ & $1 b, 1 c$ & - & 3.3 .1 & - \\
\hline 1.1 & $\begin{array}{c}\text { Non-compliance of } \\
\text { Charging cable - assembly } \\
\text { (e.g. non-correlation of } \\
\text { electrical and / or } \\
\text { mechanical, thermal, etc. } \\
\text { and dimensional } \\
\text { characteristics with station } \\
\text { characteristics) }\end{array}$ & $1 b, 1 c$ & - & 3.3 .1 & 10 \\
\hline 1.2 & $\begin{array}{l}\text { Non-compliance of vehicle } \\
\text { coupler (e.g non-correlation } \\
\text { of electrical and / or } \\
\text { mechanical, thermal, etc. } \\
\text { characteristics with the } \\
\text { characteristics of the } \\
\text { station) }\end{array}$ & $1 b, 1 c$ & $\begin{array}{l}11 \\
12\end{array}$ & 3.3 .1 & 9 \\
\hline 2. & $\begin{array}{l}\text { Design, dimension, } \\
\text { finishing, surface }((\mathrm{ex} \text { : } \\
\text { unfinished surfaces, etc)) }\end{array}$ & $1 b, 1 c$ & - & 3.3 .1 & $\begin{array}{l}6.4 .3 .108 \\
101.1 .3\end{array}$ \\
\hline 3. & $\begin{array}{l}\text { Defective operation in case } \\
\text { of damage to the main / } \\
\text { electrical installation }\end{array}$ & $1 \mathrm{c}$ & - & 3.3 .1 & $\begin{array}{c}5 \\
6.4 .3 .101\end{array}$ \\
\hline 4. & $\begin{array}{l}\text { Charging functions, } \\
\text { including optional ones }\end{array}$ & $1 \mathrm{c}$ & - & 3.3 .1 & 6 \\
\hline 5. & $\begin{array}{l}\text { Lack of interlocking and } \\
\text { locking elements in case of } \\
\text { intentional or unintentional } \\
\text { disconnection of vehicle } \\
\text { coupler }\end{array}$ & $3 \mathrm{c}$ & - & 3.3 .1 & $\begin{array}{l}6.4 .3 .103 \\
6.4 .3 .104\end{array}$ \\
\hline 6. & $\begin{array}{l}\text { Lack or non-compliance } \\
\text { protection against the } \\
\text { emergency shutdown }\end{array}$ & $1 \mathrm{c}$ & - & 3.3 .1 & 6.4.3.114 \\
\hline 7. & $\begin{array}{l}\text { Protection against electric } \\
\text { shock }\end{array}$ & $2 a, 2 b, 2 d$ & - & 3.3 .2 .2 & 7 \\
\hline
\end{tabular}




\begin{tabular}{|c|c|c|c|c|c|}
\hline \multirow[b]{2}{*}{$\mathrm{S} / \mathrm{N}$} & \multirow[b]{2}{*}{$\begin{array}{l}\text { Technical and safety } \\
\text { requirements on }\end{array}$} & \multicolumn{3}{|c|}{ Safety requirements } & \multirow[b]{2}{*}{$\begin{array}{l}\text { Technical } \\
\text { condition } \\
\text { IEC } 61851 \\
\quad 23\end{array}$} \\
\hline & & $\begin{array}{l}\text { Objectives } \\
\text { GD no. } \\
409 / 2016\end{array}$ & $\begin{array}{l}\text { Legal } \\
\text { provision } \\
\text { Law no. } \\
34 / 2017\end{array}$ & $\begin{array}{c}\text { Legal } \\
\text { provision } \\
\text { GD no. } \\
1146 / 2006\end{array}$ & \\
\hline 7.1 & $\begin{array}{c}\text { Non-compliance protection } \\
\text { against direct contact (e.g } \\
\text { accessibility of live parts } \\
\text { after opening the doors / } \\
\text { lids) } \\
\text { Disconnection of EV } \\
\text { (remanent voltage above } \\
\text { allowable limit) } \\
\end{array}$ & & - & 3.3.2.2 & $\begin{array}{c}7 \\
101.1 .2 \\
7.2 .3 .1\end{array}$ \\
\hline 7.2 & $\begin{array}{l}\text { Non-compliance of } \\
\text { protection against indirect } \\
\text { contact measures (e.g non- } \\
\text { conforming earthing } \\
\text { installation, electrical } \\
\text { supply installation where } \\
\text { the ground is common to } \\
\text { the protection earth) }\end{array}$ & 2 & - & 3.3.3.1. & 6.4 .3 .2 \\
\hline 7.3 & $\begin{array}{l}\text { No additional protection } \\
\text { measures }\end{array}$ & 2 & - & 3.3.3.1 & 7.4 \\
\hline 7.4 & $\begin{array}{c}\text { Dielectric withstand } \\
\text { characteristics below the } \\
\text { permissible limit }\end{array}$ & 2 & - & 3.3 .1 & 11.4 \\
\hline 7.5 & $\begin{array}{c}\text { Insulation resistance below } \\
\text { the permissible limit }\end{array}$ & 2 & - & 3.3 .1 . & $\begin{array}{c}11.5 \\
6.4 .3 .106 \\
\end{array}$ \\
\hline 7.6 & $\begin{array}{l}\text { Clearances and creepage } \\
\text { distances below the } \\
\text { permissible limit }\end{array}$ & 2 & - & 3.3.1. & 11.6 \\
\hline 7.7 & $\begin{array}{c}\text { Leakage-touch-current } \\
\text { below the permissible limit }\end{array}$ & 2 & - & 3.3 .1 . & 11.7 \\
\hline 8. & $\begin{array}{l}\text { Mechanical (eg impact } \\
\text { strength below allowable } \\
\text { limit) }\end{array}$ & $3 a$ & - & 3.3.1.2 & 4 \\
\hline 9. & $\begin{array}{l}\text { Thermal (eg flammability } \\
\text { and / or flame probagation } \\
\text { below the permissible limit) }\end{array}$ & $3 \mathrm{c}$ & - & 3.3.1.2 & $\begin{array}{c}6.2 \\
6.4 .3 \cdot 103 \\
6.4 .3 .104 \\
\end{array}$ \\
\hline 10. & $\begin{array}{l}\text { Chemical (case / cable / } \\
\text { connector does not resist } \\
\text { solvents and / or fluids of } \\
\text { electric or hybrid vehicles) }\end{array}$ & $3 b$ & - & 3.3 .1 .2 & - \\
\hline 11. & $\begin{array}{l}\text { Environment (e.g.: case / } \\
\text { cable / connector resistant } \\
\text { to extreme temperature } \\
\text { condition, UV, water) }\end{array}$ & $3 b$ & - & 3.3 .1 .2 & $\begin{array}{c}12.10 \\
12.9\end{array}$ \\
\hline 12. & $\begin{array}{l}\text { Electromagnetic } \\
\text { compatibility }\end{array}$ & $3 b$ & - & 3.3 .1 .2 & 11.12 \\
\hline 13. & $\begin{array}{l}\text { Communication between } \\
\text { EV and d.c. EV charging } \\
\text { station (e.g. erroneous or } \\
\text { incomplete information) }\end{array}$ & $1 \mathrm{c}$ & - & 3.3 .1 & $\begin{array}{c}6.4 .1 \\
6.4 .2 \\
102\end{array}$ \\
\hline
\end{tabular}




\begin{tabular}{|c|c|c|c|c|c|}
\hline \multirow{2}{*}{$\mathrm{S} / \mathrm{N}$} & $\begin{array}{c}\text { Technical and safety } \\
\text { requirements on }\end{array}$ & $\begin{array}{c}\text { Objectives } \\
\text { GD no. } \\
409 / 2016\end{array}$ & $\begin{array}{c}\text { Legal } \\
\text { provision } \\
\text { Law no. } \\
34 / 2017\end{array}$ & $\begin{array}{c}\text { Legal } \\
\text { provision } \\
\text { GD no. } \\
1146 / 2006\end{array}$ & $\begin{array}{c}\text { Technical } \\
\text { condition } \\
\text { IEC 61851- } \\
23\end{array}$ \\
\hline 14. & Non-compliance marking & $1 \mathrm{a}$ & - & - & $\begin{array}{c}16 \text { din EN } \\
\text { IEC 61851-1 }\end{array}$ \\
\hline 15. & $\begin{array}{c}\text { Instructions (ex: erroneous } \\
\text { and / or missing } \\
\text { information) }\end{array}$ & $1 \mathrm{a}$ & - & - & 16 din EN \\
IEC 61851-1
\end{tabular}

Within the research paper, the case study is being implemented in the analysis stage of the documentation presented by a manufacturer of charging stations for charging electric vehicles in DC and the phase of visual examinations, electrical, mechanical and climatic tests.

During the case studies, the analysis and evaluation of the conformity of the charging stations in use with the safety and health identification requirements were performed, being highlighted a series of non-conformities related to ensuring protection against electric shock by indirect touch (lack of additional protection measure against electric shock by indirect touch). The non-compliance, in most cases, was also generated by the accompanying documents (technical book, instructions for use), which did not comply with the objectives provided by GD no. 409/2016 and the clauses of the standard SR EN 61851-23: 2014 .

At a percentage of $6 \%$ of the charging stations, it was reported that the declared degree of protection was not correlated with the environmental conditions at the installation points.

Most of the analysed charging stations are used outdoors. Many manufacturers stated that they operate in the temperature range $-30^{\circ} \mathrm{C} \ldots+60^{\circ} \mathrm{C}$. In the analysed cases, it was found that the manufacturers did not perform functional tests after conditioning at the declared extreme temperatures.

Following the studies performed on different types of products/equipment within the Electrical and Mechanical Risks Laboratory from INCDPM "Alexandru Darabont", Bucharest, it was found that specific electronic components do not work at extreme temperatures following climatic conditioning at different cycles of extreme temperatures and humidity. Microclimate conditions can decisively influence equipment housing safety in insulation degradation, leading to a high risk for workers [9].

The standard SR EN IEC 61851-1: 2019 provides for functional tests on wet heat (point 12.9), functional tests at minimum temperature (point 12.10) and verification of insulation resistance and leakage current after functional tests on wet heat and functional tests at minimum temperature [4], which must also be performed on these categories of WE.

During the study, checks were made on the insulation resistance in the dry state and the electrical leakage current for the housings of two models of DC charging stations. The electrical checks were performed after the mechanical test - shock. Due to the size of the products tested, no functional climatic tests were performed. In figure no. 2 presents the results of dielectric strength checks, performed by the test procedures established in the laboratory, for the housings of the two equipment models.

The test voltage at the industrial frequency of $50 \mathrm{~Hz}$ was applied to the value of $5.25 \mathrm{kV}$ for 60 seconds.

In the case of housing 2 variations of the leakage current were registered. 


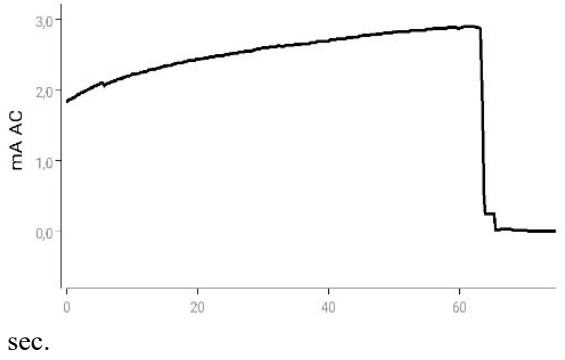

Fig. 2a - housing model 1 behaviour when applying $5.25 \mathrm{kV}$ test voltage

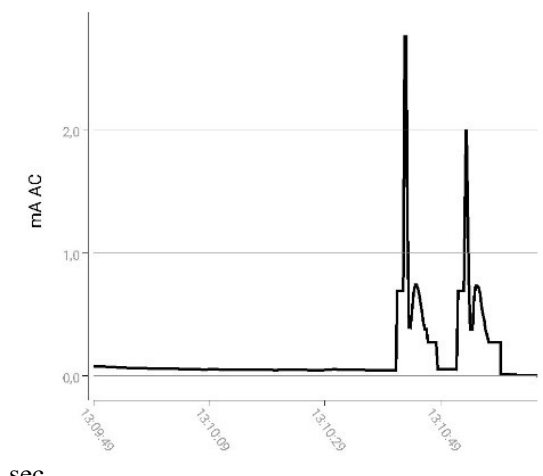

Fig. 2b - housing model 2 behaviour when applying $5.25 \mathrm{kV}$ test voltage

Fig. 2. The results of testing the dielectric strength

Measurement of insulation resistance is one of the necessary periodic tests to ensure the safety of workers and the safety of electrical installations. The reason these tests are done is to prevent accidents caused by electric shock and damage to equipment [10].

The physical and insulating properties of the housings can be influenced by electrical and electronic components' operation so that material with high dielectric losses will heat up more than one with low dielectric losses [11, 17].

In the case of dielectric strength checks in alternating current, they were performed on a single model of charging station, in a dry state, following the clauses of point 12.7 (2) of the standard SR EN 61851-1: 2019. A three-phase electrical installation powers the charging station with a charging power of $50 \mathrm{~kW}$. From the point of view of protection against electric shocks, it is class I equipment. At the industrial frequency of $50 \mathrm{~Hz}$, the test voltage was applied, increasing to the value of $1.6 \mathrm{kV}$, for 60 seconds in common (between the circuits about all exposed conductive parts - ground) and differently (between each independent electrical circuit and all other exposed conductive parts). The measured values of the leakage current did not exceed one mA. Due to the size of the product tested, no climatic functional tests have been performed before. In the analysed documents, it was identified that the environmental conditions regarding the relative humidity, the climatic zone, the altitude up to which it can be used, the atmosphere are not specified. The maintenance activities and the new risks identified for this category of MS can be managed both by technical prevention tools used in the conformity assessment, technical diagnosis and certification procedures and by specific verification and control tools that allow the effective monitoring of planned maintenance activities at charging stations for charging electric vehicles in DC.

In this sense, within the research paper was developed a methodology for conformity assessment and testing on charging stations for charging electric vehicles, customized for charging in DC, to certify the presumption of conformity with the relevant safety objectives for this category of WE.

\section{Conclusion}

The development and expansion of electric vehicle charging infrastructure involve new jobs and, like any new technology, also involves risks of injury and occupational disease. In this sense, users, specialized personnel with the installation, commissioning, and maintenance of systems or equipment/charging stations / electric vehicles must be competent in this field and must be informed and aware of the risks of occupational injury to which they may be exposed. 
The study presents the results of research on identifying technical and safety requirements specific to a category of work equipment used to charge electric vehicles - DC charging systems, research in the field of occupational safety and health-related to the production of goods and services for saving and electricity management.

The technical and safety requirements applicable to direct current electric vehicle charging systems provide the criteria underlying the management of the necessary risk management, manufacturers and users, and the entities that ensure the maintenance of these types of equipment to adopt solutions. With a high technical and safety level.

The identification and assessment of the risks of accidents and occupational diseases, the establishment of the impact, and the mode of exposure of workers and users are based on assessing compliance of loading equipment with technical and safety requirements specific to these categories of work equipment used to charge electric vehicles.

\section{References}

1. NSI - TEMPO program 2021 [Accessed 16.04.2021]

2. LAW no. 34 of March 27, 2017, on the installation of infrastructure for alternative fuels, (2017)

3. https://www.plugshare.com/ [Accessed 28.07.2021]

4. INCDPM, Operational study of the specific problems in the field of car power supply, identifying the main problems, identifying risks and consequences that may result from an unforeseen event that turns into an accident Risk structure - causes - consequences draft prevention measures. Specific ontology, (2020-2021)

5. J Miličić, Ž Hederić, et. al., Safety rules for use in electric vehicle charging infrastructure, Safety Engineering, 117-127, (2016)

6. Ming-Hung Lu, Ming Une Jen, Safety design of electric vehicle charging equipment, World Electric Vehicle Journal Vol. 5, 1017-1024, (2012)

7. SR EN 61851-23:2014 Electric Vehicle Conductive Charging System - Part 23: DC Electric Vehicle Charging Station (2014)

8. SR EN 61851-1:2019 Electric vehicle conductive charging system - Part 1: General requirements (2019)

9. V.M. Pasculescu. N.I. Vlasin, I. Nivcolae, M.C. Suvar, E. Ghicioi, D. Florea Considerations on impact resistance tests for electrical equipment used in explosive atmospheres, SGEM 2016 Albena, Bulgaria, Vol. II (2016)

10. R Dobra, D Pasculescu, G. Marc, M Risteiu and A Antonov, Designing and Implementation a Lab Testing Method for Power Cables Insulation Resistance According with STAS 10411-89, SR EN ISO/CEI/17025/2005, IOP Conf. Series: Materials Science and Engineering, 209 (2017)

11. P. Dašić, C. Hutanu, V. Jevremović, R. Dobra, M. Risteiu, I. Ileana, High Accuracy Investigation of Microwave Absorption in Polymer Electrical Components on Motherboard of Computers, IOP Conf. Series: Materials Science and Engineering 209 (2017)

12. GD nr. 409/2016 - Laying down the conditions for making available on the market of low-voltage electrical equipment (2016)

13. Directive 2014/35/UE on the harmonisation of the laws of the Member States relating to the making available on the market of electrical equipment designed for use within certain voltage limits (recast), (2014)

14. GD 1146/2006 concerning the minimum safety and health requirements for the use of work equipment by workers at work, (2016)

15. Directive $89 / 655 / \mathrm{CEE}$ concerning the minimum safety and health requirements for the use of work equipment by workers at work, (1989)

16. https://lektri.co/ro/ [Accessed 28.07.2021]

17. R. Dobra, G. Buica, D. Pasculescu, M. Leba, Safety management diagnostic method regarding work cost accidents from electrical power installations, Proceedings of the 1st International Conference on Industrial and Manufacturing Technologies, (2013) 